Cite this article: Polchaninova N.Yu. New data on the spider fauna (Araneae) of the Penza Region (Russia). The Journal of V. N. Karazin Kharkiv National University, Series "Biology", 2020, 35, 110-116.

UDC: 595.44

\title{
New data on the spider fauna (Araneae) of the Penza Region (Russia) N.Yu. Polchaninova
}

Arachnological research in the Penza Region was conducted in the 1980s and in the mid-2000s only. Initially, a list of 112 species was published and spider distribution within five types of habitats throughout the region was analyzed (Pyatin, 1988). Later on, spiders were studied in four segments of the Privolzhskaya Lesostep Nature Reserve and the species lists for each segment were compiled (Polchaninova, 2008, 2015a, b, 2020). In total, 273 spider species of 23 families were recorded from the reserve. The segments are located in four administrative districts of the region. The present paper provides an annotated list of 71 spider species recorded for the first time from the Lunino District. The material was collected by pitfall trapping in 2004 and 2005 in five habitats in the Nature Monument Solontsovaya Steppe: meadow steppe on the chernozem soil on a gentle slope (33 species), steppe on the clayey soil on a steep gully slope (33 species), steppe on the solonetz soil on a gentle slope (43 species), sand and clay quarry (28 species), and bank of a pond (29 species). The most abundant was the spider assemblage of the meadow steppe (736 individuals) dominated by Pardosa fulvipes (62\% of total spiders collected in the habitat). Other spider assemblages were less abundant (minimum 243 individuals on the pond bank and maximum 324 individuals in the solonetz steppe), and their dominance structure was more uniform. The dominant complexes consisted of Gnaphosa lugibris, Haplodrassus signifier and Xerolycosa miniata in the clayey steppe (53\% of total spiders in the habitat), X. miniata, $P$. fulvipes, $P$. palustris, and $P$. agrestis in the solonetz steppe $(60 \%), X$. miniata and $P$. fulvipes in the quarry (57 \%), and $P$. fulvipes, $P$. palustris, and Diplostyla concolor on the pond bank (63.5\%). Thus, Pardosa fulvipes and Xerolycosa miniata were the most numerous species at the study site. A high abundance of both species was also observed in the Borok segment of the Privolzhskaya Lesostep Nature Reserve, which suggests similarity of ecological conditions in the grassland habitats of both localities. One species, Mastigusa arietina, is new to the Penza Region. Taking into account 40 species recorded by M. Pyatin (1988) but absent from our collection, the spider fauna of the Penza Region numbers 313 species of 27 families.

Key words: araneofauna, species distribution, steppe habitats, protected areas, Volga Upland.

About the author:

N.Yu. Polchaninova - V.N. Karazin Kharkiv National University, Svobody Sq., 4, Kharkiv, Ukraine, 61022, n.polchaninova@karazin.ua, http://orcid.org/0000-0003-4605-8788

\section{Introduction}

The first information about the araneofauna of the Penza Region dates back to the beginning of the $20^{\text {th }}$ century (Skorikov, 1903; Greze, 1911). Then, after a gap of more than 70 years, M. Pyatin (1988) published a list of 112 species of 15 families. Spiders were collected in five types of habitats, but the collecting localities were not provided in the paper. In 2004 and 2005, an arachnological research was conducted in the Nature Reserve Privolzhskaya Lesostep. As a result, the checklists of spiders of the four reserve's segments were compiled, and a total of 273 species was listed (Polchaninova, 2008, 2015a, b, 2020).

The aim of the present paper is to make an annotated list of spiders collected in a new locality in the Penza Region, and to summarize knowledge about the regional araneofauna.

\section{Material and methods}

The study area, a Nature Monument Solontsovaya Steppe, is located in the Lunino District of the Penza Region between the villages of Nazaryevka $53^{\circ} 36^{\prime} 29^{\prime \prime} \mathrm{N} 44^{\circ} 59^{\prime} 04^{\prime \prime} \mathrm{E}$ and Ferlyudinka $53^{\circ} 36^{\prime} 01^{\prime \prime} \mathrm{N}$ $454^{\circ} 03^{\prime} 09^{\prime \prime} \mathrm{E}$, near an abandoned village of Merlinka. The site is characterized by a strongly dissected relief of erosion-landslide origin formed by deep circus depressions and a branched system of ravines and gullies.

Five habitats located along the landscape transect were studied: meadow steppe on chernozem soil on a gentle slope (abbreviation in the species list - MdSt); steppe on a steep clayey slope dominated by Galatella sp. - CISt; secondary steppe on solonetz soil on a gentle slope dominated by Silaum silaus (L.) Schinz \& Thell) - SISt (in USDA soil taxonomy, the solonetz corresponds to the sodium-rich Alfisols); sand and clay quarry - Quar; bank of a pond - PB.

Spiders were collected in 2004 and 2005 by pitfall trapping. Cropped two-liter plastic bottles were used as traps and set up in a line of 10 traps at a distance $10 \mathrm{~m}$ from each other. The sampling period started in mid-June and lasted to early October. The traps were checked out monthly; in total, 1823 individuals of 
adult spiders were collected. A list of species is provided with a code of habitat (see above), number of males/females and collecting date(s). The nomenclature follows the World Spider Catalog (WSC, 2020).

The dry grassland spider fauna of the Solontsovaya Steppe was compared to those of the Ostrovtsovskaya Steppe and Kuncherovskaya Lesostep segments of the Privolzhskaya Lesostep Nature Reserve. The reserve's segments are studied better and have lager areas. The Ostrovtsovskaya Steppe lies southernmost, while the Solontsovaya Steppe is located northernmost. The Kuncherovskaya Lesostep hosts a drier variant of meadow and sandy steppe.

\section{Results and discussion}

The collected spiders belong to 71 species in 15 families. Three families are the most species-rich: Lycosidae - 15 species, Gnaphosidae - 13 species, and Linyphiidae - 12 species. They are easily caught by pitfall traps and dominate in the ground-dwelling spider assemblages in various landscapes and habitats. Their ratio in local faunas depends on climatic conditions and habitat types. Linyphiidae is the most diverse family of Palearctic prevailing in high latitudes in mesic and wet habitats (Eskov, 1981). In dry grassland ecosystems, it is most diverse in mesic meadows and meadow steppes (Polchaninova, Prokopenko, 2013). Gnaphosidae is the richest in the south of Palearctic, while Lycosidae does not show a clear latitudinal dependence.

Family Araneidae

\section{List of species}

1. Araneus quadratus Clerck, 1757: SISt, 1f, 18.08-24.09.2004; Ouar, 1f, 18.08-24.09.2004.

2. Hypsosinga sanguinea (C.L. Koch, 1844): SISt, If juv., 18.08-24.09.2004; BP, 1f, 20.0919.10.2005.

3. Mangora acalypha (Walckenaer, 1802): MdSt, 1f, 18.06-12.07.2005.

Family Cheiracanthiidae

4. Cheiracanthium erraticum (Walckenaer, 1802): CISt, 1f, 15.06-12.07.2005.

Family Clubionodae

5. Clubiona caerulescens L. Koch, 1867: BP, 1f, 18.08-24.09.2004.

6. Clubiona neglecta O. Pickard-Cambridge, 1866: MdSt, 1f, 20.07-17.08.2004; 1m, 18.0612.07.2005; CISt, 2f, 15.06-12.07.2005; SISt, 1f, 27.06-19.07.2004; 1f, 15.06-12.07.2005.

Family Gnaphosidae

7. Drassodes pubescens (Thorell, 1856): MdSt, 1f, 20.07-17.08.2004; 1f, 18.06-12.07.2005; 1f, 20.09-19.10.2005; SISt, 3m, 1f, 27.06-19.07.2004; 2f, 18.08-24.09.2004.

8. Drassyllus praeficus (L. Koch, 1866): MdSt, 1m, 18.06-12.07.2005; CISt, 1m, 5f, 15.0612.07.2005; SISt, 3m, 1f, 15.06-12.07.2005; Quar, 1f, 27.06-19.07.2004; 2m, 2f, 20.0717.08.2004.

9. Drassyllus pusillus (C.L. Koch, 1833): MdSt, 33m, 9f, 18.06-12.07.2005; 2f, 20.09-19.10.2005; CISt, 7f, 15.06-12.07.2005; SISt, 1m, 4f, 15.06-12.07.2005; Quar, 3f, 27.06-19.07.2004; 2m, 5f, 20.07-17.08.2004; 1f, 15.06-12.07.2005.

10. Gnaphosa lugubris (C.L. Koch, 1839): MdSt, 1m, 18.06-12.07.2005; CISt, 5f, 20.07-17.08.2004; 1f, 18.08-24.09.2004; 31m, 14f, 15.06-12.07.2005; 1f, 20.09-19.10.2005; Quar, 1f, 20.0717.08.2004; BP, 5m, 3f, 18.06-12.07.2005.

11. Haplodrassus signifer (C.L. Koch, 1839): MdSt, 34m, 9f, 18.06-12.07.2005; CISt, 1m, 20.0717.08.2004; 15m, 6f, 15.06-12.07.2005; SISt, 1f, 20.07-17.08.2004; 1f, 27.06-19.07.2004; Quar, 9m, 7f, 20.07-17.08.2004.

12. Haplodrassus silvestris (Blackwall, 1833): SISt, 1f, 15.06-12.07.2005.

13. Haplodrassus umbratilis (L. Koch, 1866): Quar, 1m, 27.06-19.07.2004.

14. Micaria formicaria (Sundevall, 1831): MdSt, 1f, 20.07-17.08.2004; CISt, 1m, 15.06-12.07.2005; $1 \mathrm{~m}, 20.09-19.10 .2005$; SISt, 1m, 1f, 20.07-17.08.2004; Quar, 1f, 15.06-12.07.2005; BP, 1f, 18.06-12.07.2005; 1m, 20.09-19.10.2005.

15. Micaria pulicaria (Sundevall, 1831): CISt, 2f, 15.06-12.07.2005.

16. Zelotes azsheganovae Esyunin, Efimik, 1992: MdSt, 2m, 18.06-12.07.2005; SISt, 1f, 27.0619.07.2004; 1f, 18.08-24.09.2004; Quar, 1m, 15.06-12.07.2005; BP, 1f, 18.08-24.09.2004.

17. Zelotes electus (C.L. Koch, 1839): SISt, 1m, 15.06-12.07.2005.

18. Zelotes latreillei (Simon, 1878): BP, 2m, 1f, 18.06-12.07.2005. 
19. Zelotes longipes (L. Koch, 1866): CISt, 1m, 1f, 18.08-24.09.2004; 2f, 15.06-12.07.2005; SISt, 1f, 18.08-24.09.2004; Quar, 2m, 18.08-24.09.2004.

Family Hahniidae

20. Mastigusa arietina (Thorell, 1871): SISt, 2f, 20.07-17.08.2004.

Family Linyphiidae

21. Agyneta rurestris (C.L. Koch, 1836): MdSt, 1m, 20.07-17.08.2004; CISt, 1f, 20.07-17.08.2004; SISt, 2f, 27.06-19.07.2004; 1f, 18.08-24.09.2004; Quar, 1f, 20.07-17.08.2004.

22. Centromerus sylvaticus (Blackwall, 1841): CISt, 1f, 18.08-24.09.2004; 1f, 15.06-12.07.2005; SISt, 1m, 18.08-24.09.2004; 2m, 20.09-19.10.2005; 15.06-12.07.2005; BP, 15m, 3f, 18.0612.07.2005.

23. Diplostyla concolor (Wider, 1834): MdSt, 1m, 3f, 20.07-17.08.2004; 2m, 1f, 15.06-12.07.2005; $1 \mathrm{~m}, 20.09-19.10 .2005$; CISt, 3f, 27.06-19.07.2004; 1f, 15.06-12.07.2005; SISt, 1f, 15.0612.07.2005; Quar, 1f, 20.07-17.08.2004; BP, 4m, 6f, 17.08--24.09.2004; 7m, 15f, 8.0612.07.2005.

24. Erigone atra Blackwall, 1833: Quar, 1m, 20.07-17.08.2004; 4m, 6f, 18.08-24.09.2004.

25. Erigone dentipalpis (Wider, 1834): MdSt, 1m, 20.07-17.08.2004; SISt, 1f, 20.07-17.08.2004.

26. Improphantes geniculatus (Kulczyński, 1898): CISt, 1f, 18.08-24.09.2004; SISt, 1f, 20.0717.08.2004.

27. Micrargus subaequalis (Westring, 1851): MdSt, $1 \mathrm{~m}, 20.07-17.08 .2004$.

28. Microlinyphia pusilla (Sundevall, 1830): MdSt, 1m, 3f, 20.07-17.08.2004; CISt, 1f, 18.0824.09.2004; SISt, 1f, 20.07-17.08.2004; 1f, 15.06-12.07.2005.

29. Oedothorax retusus (Westring, 1851): SISt, $2 \mathrm{~m}, 20.07-17.08 .2004$.

30. Pocadicnemis pumila (Blackwall, 1841): BP, 1f, 18.06-12.07.2005.

31. Stemonyphantes lineatus (Linnaeus, 1758): MdSt, 1f, 20.07-17.08.2004; 10m, 8f, 18.0612.07.2005; Quar, 2f, 27.06-19.07.2004; 1m, 20.07-17.08.2004; 1m, 1f, 15.06-12.07.2005.

32. Trichopterna cito (O. Pickard-Cambridge, 1872): SISt, 1m, 18.08-24.09.2004.

Family Liocranidae

33. Agroeca brunnea (Blackwall, 1833): BP, 2f, 18.08-24.09.2004; 2m, 20.09-19.10.2005.

34. Agroeca cuprea Menge, 1873: MdSt, 1f, 20.07-17.08.2004; 1m, 20.09-19.10.2005; SISt, 1f, 15.06-12.07.2005; Quar, 5m, 18.08-24.09.2004; 1f, 15.06-12.07.2005.

35. Agroeca lusatica (L. Koch, 1875): MdSt, 1m, 18.08-24.09.2004; 1f, 18.06-12.07.2005; CISt, 3f, 15.06-12.07.2005; SISt, 1f, 15.06-12.07.2005; BP, 3m, 1f, 20.09-19.10.2005.

36. Agroeca maculata L. Koch, 1879: MdSt, 2m, 20.09-19.10.2005; CISt, 4m, 1f, 18.08-24.09.2004; 5f, 15.06-12.07.2005; 2m, 1f, 20.09-19.10.2005; SISt, 1f, 20.07-17.08.2004; 1m, 18.0824.09.2004; Quar, 1f, 18.08-24.09.2004; 1f, 15.06-12.07.2005; BP, 8m, 5f, 20.09-19.10.2005.

37. Agroeca proxima (O. Pickard-Cambridge, 1871): MdSt, 1m, 20.09-19.10.2005; BP, 10m, 1f, 18.06-12.07.2005.

Family Lycosidae

38. Alopecosa cuneata (Clerck, 1757): MdSt, 2m, 7f, 18.06-12.07.2005; SISt, 1f, 20.07-17.08.2004; 1f, 18.08-24.09.2004; 5f, 15.06-12.07.2005; Quar, 2f, 27.06-17.07.2004; 3f, 20.07-17.08.2004; BP, 2f, 18.06-12.07.2005.

39. Alopecosa farinosa (Herman, 1849): CISt, 9f, 15.06-12.07.2005; BP, 2f, 18.06-12.07.2005.

40. Alopecosa pulverulenta (Clerck, 1757): SISt, 1f, 15.06-12.07.2005; BP, 1f, 20.09-19.10.2005.

41. Alopecosa solitaria (Herman, 1879): MdSt, 1f, 20.07-17.08.2004; 1m, 18.08-24.09.2004; ClSt, $1 \mathrm{~m}, 2 \mathrm{f}, 18.08-24.09 .2004$; 1f, 15.06-12.07.2005; 3m, 1f, 20.09-19.10.2005.

42. Alopecosa taeniopus (Kulczyn'ski, 1895): MdSt, 2m, 1f, 18.08-24.09.2004; CISt, 3f, 18.0824.09.2004; 1m, 20.09-19.10.2005; SISt, 5m, 1f, 18.08-24.09.2004; Quar, 2m, 1f, 18.0824.09.2004; 1f, 15.06-12.07.2005.

43. Pardosa agrestis (Westring, 1861): MdSt, 2f, 20.07-17.08.2004; 6m, 1f, 18.06-12.07.2005; CISt, 1f, 20.07-17.08.2004; 5m, 7f, 15.06-12.07.2005; SISt, 6m, 1f, 27.06-19.07.2004; 5m, 3f, 20.0717.08.2004; 1f, 18.08-24.09.2004; 20m, 14f, 15.06-12.07.2005; Quar, 3f, 20.07-17.08.2004; 1f, 18.08-24.09.2004; 1f, 15.06-12.07.2005; BP, 1m, 1f, 18.06-12.07.2005.

44. Pardosa fulvipes (Collet, 1876): MdSt, 1m, 2f, 20.07-17.08.2004; 2f, 18.08-24.09.2004; 363m, 60f, 18.06-12.07.2005; 6f, 20.09-19.10.2005; CISt, 1f, 18.08-24.09.2004; 21m, 3f, 15.0612.07.2005; SISt, 6m, 1f, 27.06-19.07.2004; 1f, 18.08-24.09.2004; 63m, 8f, 15.06-12.07.2005; 
Quar, 20m, 1f, 27.06-17.07.2004; 36m, 3f, 20.07-17.08.2004; 11f, 15.06-12.07.2005; BP, 56m, 4f, 18.06-12.07.2005; 3f, 20.09-19.10.2005.

45. Pardosa lugubris (Walckenaer, 1802): BP, 1f, 18.08-24.09.2004.

46. Pardosa paludicola (Clerck, 1757): CISt, 1f, 15.06-12.07.2005.

47. Pardosa palustris (Linnaeus, 1758): MdSt, 1m, 23 f, 20.07-17.08.2004; 3f, 18.08-24.09.2004; 21m, 14f, 18.06-12.07.2005; 7f, 20.09-19.10.2005; CISt, 6f, 20.07-17.08.2004; 3f, 15.0612.07.2005; SISt, 4m, 6f, 20.07-17.08.2004; 6f, 18.08-24.09.2004; 11m, 6f, 15.06-12.07.2005; Quar, 4m, 10f, 20.07-17.08.2004; 1m, 15.06-12.07.2005; BP, 39f, 18.06-12.07.2005.

48. Pardosa prativaga (L. Koch, 1870): BP, 2f, 18.08-24.09.2004.

49. Piratula hygrophila (Thorell, 1872): BP, 7m, 2f, 18.08-24.09.2004.

50. Trochosa ruricola (De Geer, 1778): MdSt, 1f, 18.08-24.09.2004; SISt, 3f, 20.07-17.08.2004; 1f, 15.06-12.07.2005; BP, 1m, 18.08-24.09.2004.

51. Trochosa terricola Thorell, 1856: MdSt, 1f, 20.07-17.08.2004; 2m, 18.06-12.07.2005; 1m, 20.09-19.10.2005; CISt, 1m, 1f, 15.06-12.07.2005; SISt, 11m, 18.08-24.09.2004; Quar, 1m, 27.06-17.07.2004; BP, 1m, 2f, 18.06-12.07.2005.

52. Xerolycosa miniata (C.L. Koch, 1834): MdSt, 5m, 4f, 20.07-17.08.2004; 3f, 18.08-24.09.2004; 24m, 4f, 18.06-12.07.2005; 1f, 20.09-19.10.2005; CISt, 6m, 4f, 20.07-17.08.2004; 58m, 4f, 15.0612.07.2005; SISt, 15m, 27.06-19.07.2004; 19m, 11f, 20.07-17.08.2004; 8m, 1f, 15.0612.07.2005; Quar, 9m, 2f, 27.06-17.07.2004; 15m, 5f, 20.07-17.08.2004; 18m, 4f, 15.0612.07.2005; BP, 3m, 2f, 18.06-12.07.2005.

Family Mimetidae

53. Ero furcata : SISt, 1f, 18.08-24.09.2004; BP, 1m, 1f, 18.08-24.09.2004.

Family Philodromidae

54. Thanatus arenarius L. Koch, 1872: MdSt, 2m, 18.06-12.07.2005; Quar, 1m, 1f, 20.0717.08.2004.

55. Tibellus oblongus (Walckenaer, 1802): SISt, 1f, 18.08-24.09.2004; Quar, 1m, 20.0717.08.2004.

Family Phrurolithidae

56. Phrurolithus festivus (C.L. Koch, 1835): MdSt, 1m, 20.07-17.08.2004; 1f, 18.08-24.09.2004; CISt, 5f, 20.07-17.08.2004; SISt, 3f, 20.07-17.08.2004; Quar, 1m, 1f, 27.06-17.07.2004.

Family Salticidae

57. Aelurillus v-insignitus (Clerck, 1757): CISt, 2m, 20.07-17.08.2004; 1m, 1f, 18.08-24.09.2004.

58. Evarcha arcuata (Clerck, 1757): SISt, 1m, 20.09-19.10.2005.

59. Heliophanus auratus C.L. Koch, 1835: CISt, 1m, 20.07-17.08.2004.

60. Heliophanus flavipes (Hahn, 1832): MdSt, 1f, 20.07-17.08.2004; SISt, 1f, 20.07-17.08.2004.

61. Phlegra fasciata (Hahn, 1826): SISt, 1m, 27.06-19.07.2004.

62. Sibianor aurocinctus (Ohlert, 1865): CISt, 2f, 15.06-12.07.2005.

63. Talavera aequipes (O. Pickard-Cambridge, 1871): SISt, 2f, 27.06-19.07.2004.

Family Sparassidae

64. Micrommata virescens (Clerck, 1757): CISt, 1m, 15.06-12.07.2005.

Family Tetragnathidae

65. Pachygnatha clercki Sundevall, 1823: BP, 1m, 18.08-24.09.2004.

66. Pachygnatha degeeri Sundevall, 1830: CISt, 1m, 15.06-12.07.2005; SISt, 2m, 18.0824.09.2004; 1m, 15.06-12.07.2005; 1m, 20.09-19.10.2005; Quar, 1m, 1f, 20.07-17.08.2004; 1m, 1f, $15.06-12.07 .2005$.

Family Theridiidae

67. Asagena phalerata (Panzer, 1801): MdSt, 1m, 18.06-12.07.2005; CISt, 1m, 15.06-12.07.2005; Quar, 1f, 20.07-17.08.2004.

Family Thomisidae

68. Ozyptila praticola (C.L. Koch, 1837); BP, 1m, 18.08-24.09.2004.

69. Ozyptila scabricula (Westring, 1851): MdSt, 1f, 20.07-17.08.2004; 1f, 20.09-19.10.2005; ClSt, 1f, 20.07-17.08.2004; 1m, 18.08-24.09.2004; SISt, 2m, 20.07-17.08.2004; $1 \mathrm{~m}, 18.08-$ 24.09.2004; Quar, 1m, 27.06-17.07.2004; BP, 1m, 20.07-17.08.2004; 1m, 20.09-19.10.2005.

70. Spiracne striatipes (L. Koch, 1870): MdSt, 1f, 18.08-24.09.2004; CISt, 2m, 1f, 18.08-24.09.2004; SISt, 1f, 15.06-12.07.2005; BP, 1f, 20.07-17.08.2004.

71. Xysticus kochi Thorell, 1872: CISt, 1f, 15.06-12.07.2005. 
The individual number and proportions of the three main families in Solontsovaya Steppe varied insignificantly (Table 1); Linyphiidae prevailed in the Ostrovtsovskaya Steppe and decreased in relative (but not absolute) numbers in the Kuncherovskaya Lesostep. We found no evidences of latitudinal changes in the family species richness within the three compared protected areas. Presumably, the ratio of families was determined by the local conditions of each site.

Table 1. Species richness of the main spider families in dry grassland habitats of three protected steppe areas in the Penza Region (number of species /\%)

\begin{tabular}{|l|c|c|c|}
\hline \multirow{2}{*}{ Families } & \multicolumn{2}{|c|}{ Nature Reserve Privolzhskaya Lesostep } & \multirow{2}{*}{$\begin{array}{c}\text { Nature Monument } \\
\text { Solontsovaya Steppe }\end{array}$} \\
\cline { 2 - 3 } & $\begin{array}{c}\text { Ostrovtsovskaya } \\
\text { Steppe segment }\end{array}$ & $\begin{array}{c}\text { Kuncherovskaya } \\
\text { Lesostep segment }\end{array}$ & $11 / 19.0$ \\
\hline Gnaphosidae & $7 / 9.0$ & $17 / 17.9$ & $10 / 17.2$ \\
\hline Linyphiidae & $14 / 18.4$ & $13 / 13.7$ & $12 / 20.7$ \\
\hline Lycosidae & $9 / 1.8$ & $17 / 17.9$ & $58 / 100$ \\
\hline Total species & $76 / 100$ & $94 / 100$ & \\
\hline
\end{tabular}

The solonetz steppe was the richest in the number of spider species (43), the meadow and the clayey steppes hosted 33 and 35 species, respectively; 28 species were found in the quarry, and 29 species on the pond bank. The most abundant was the spider assemblage of the meadow steppe (736 individuals) dominated by Pardosa fulvipes (62 \% of total spiders in the habitat). In other habitats, we collected 324 spiders in the solonetz steppe, 295 in the clayey steppe, 223 in the quarry, and 201 on the pond bank. A correlation of the species dominance was more balanced (Table 2). P. fulvipes occurred in all studied habitats, being a dominant in the four of them. Xerolycosa miniata was the second-abundant species, preferring the clayey steppe and the quarry ( $25 \%$ in each habitat). The dominant complexes (species with relative abundance over $10 \%$ ) consisted of one species in the meadow steppe, two species in the quarry, tree species in the clayey steppe and on the pond bank, and four species in the solonetz steppe (Table 2).

Table 2. Dominant complexes (in bold) of spider assemblages in the study habitats of the Solontsovaya Steppe (\% of total individuals in the habitat)

\begin{tabular}{|l|c|c|c|c|c|}
\hline \multirow{2}{*}{ Species } & \multicolumn{5}{c|}{ Habitats } \\
\cline { 2 - 6 } & meadow steppe & clayey steppe & solonetz steppe & quarry & pond bank \\
\hline Gnaphosa lugbris & 0,1 & $\mathbf{1 7 . 3}$ & - & - & 3.3 \\
\hline Haplodrassus signifier & 5.9 & $\mathbf{1 0 . 9}$ & 0.6 & 7.2 & - \\
\hline Diplostyla concolor & 1.1 & 1.4 & 0.3 & 0.4 & $\mathbf{1 3 . 2}$ \\
\hline Pardosa agrestis & 1.2 & 4.4 & $\mathbf{1 5 . 4}$ & 2.2 & 0.8 \\
\hline P. fulviipes & $\mathbf{6 1 . 5}$ & 8.5 & $\mathbf{2 4 . 8}$ & $\mathbf{3 1 . 8}$ & $\mathbf{2 6 . 0}$ \\
\hline P. palustris & 9.4 & 2.7 & $\mathbf{1 0 . 2}$ & 6.7 & 16.1 \\
\hline Xerolycosa miniata & 5.6 & $\mathbf{2 4 . 5}$ & $\mathbf{2 0 . 1}$ & $\mathbf{2 4 . 7}$ & 4.1 \\
\hline Others & 38.5 & 47.3 & 29.5 & 43.5 & 36.5 \\
\hline
\end{tabular}

The high abundance of $P$. fulvipes and $X$. miniata was also observed in the floodplain meadows of the Borok segment of the Privolzhskaya Lesostep Nature Reserve (Polchaninova, 2015a), which suggests similarity of ecological conditions in the grassland habitats of both localities. In the Ostrovtsovskaya Steppe and Kuncherovskaya Lesostep, $P$. fulvipes was numerous in mesic and wet meadows at the gully bottoms. $X$. miniata was collected as singletons in the former site, while in the latter two it occurred in the steppe, sandy ravines, meadows and open pine plantations, being especially numerous in abandoned fields (Polchaninova, 2008, 2020).

One species, Mastigusa arietina, is new to the fauna of the Penza Region. It is widely distributed in Europe but rare and difficult to catch, because it lives under the bark of trees, in anthills and/or caves (Nentwig et al., 2020). Currently, 313 species in 27 families are known for the Penza Region: Ostrovtsovskaya Steppe (Kolyshley District) - 128 species, Borok (Kameshkir District) - 140 species, 
Verkhovya Sury (Kuznetsk District) - 97 species, Kuncherovskaya Lesostep (Kameshkir, Kuznetsk and Neverkino districts) - 216 species, Solontsovaya Steppe (Lunino District) - 71 species, and 40 species recorded by A. Pyatin (1988) but absent from our collection. Zelotes pseudagaiilcus Ponomarev, 2007 was listed erroneously in the Verkhovya Sury (Polchaninova, 2015b); actually, this record refers to Z. clivicola. Thus, the total number of species in the Privolzhskaya Lesostep Nature Reserve is 272. In a list published by A. Pyatin (1988), Pardosa monticola (Clerck, 1757) is also a misidentification, since the species range extends from Western Europe to the western part of the East European Plain (Baltic countries, Belarus and Western Ukraine). Thetragnatha derghami Scopoli, 1763 is a synonym of T. domestica (Clerck, 1757); a record of Pisaura mirabilis (Clerck, 1757) needs confirmation as in that period this species was not distinguished from $P$. novicia.

A list of spider species of the Penza Region is far from being complete. For comparison, the araneofaunas of the neighbouring Ulyanov and Samara regions are much richer, 436 and 485 species, respectively (Alekseenko, 2019; Belostudtsev, 2018). Therefore, further arachnological research in the area in question is badly needed.

\section{Acknowledgements}

The author is thankful to I.P. Lebyazhinskaya, the deputy director for research work of the Privolzhskaya Lesostep Nature Reserve, for collecting the material and providing the information about the study site.

\section{References}

Alekseenko Yu.G. (2019). Zoogeographical analysis of araneofauna of steppous plots of the Ulyanovsk Region with data on area expanding of several species. Izvestiya of Saratov University. New series. Series: Chemistry. Biology. Ecology, 19(2), 223-228. https://doi.org/10.18500/1816-9775-2019-19-2-223-228. (in Russian)

Belosludtsev E.A. (2018). The new finds of spiders (Arachnida: Aranei) in the Volga Region forest-steppe zone. Izvestiya of Saratov University. New series. Series: Chemistry. Biology. Ecology, 18(2), $196-199$. https://doi.org/10.18500/1816-9775-2018-18-2-196-199. (in Russian)

Eskov K.Yu. (1981). Analysis of the special distribution of spiders in the Yenisei taiga. Zoologicheskiy Zhurnal, 60(3), 353-362. (in Russian)

Greze N.S. (1911). Addition to the spider species list of the Moscow Government. Izvestiya obshchestva lyubiteley yestestvosnaniya, antropologii i etnografii, 98, 55-61. (in Russian)

Nentwig W., Blick T., Gloor D. et al. (2020). Araneae. Version 10.2020. https://www.araneae.nmbe.ch. Polchaninova N.Yu. (2008). Materials to the spider fauna (Aranei) of the 'Ostrovtsovskaya Steppe' sector of the 'Privolzhskaya Lesostep' Nature Reserve. Caucasian Entomological Bulletin, 4(2), 151-161. (in Russian) Polchaninova N.Yu. (2015a). Spiders (Aranei) of the 'Privolzhskaya Lesostep' Nature Reserve (Penza Area, Russia). 1. Sector 'Borok'. Belgorod State University Scientific Bulletin. Series of Natural Sciences, 9(206), issue 31, 43-50. (in Russian)

Polchaninova N.Yu. (2015b). Spiders (Aranei) of the 'Privolzhskaya Lesostep' Nature Reserve (Penza Area, Russia). 2. Sector 'Verkhovia Sury'. Belgorod State University Scientific Bulletin. Series of Natural Sciences, 15(212), issue 32, 67-73. (in Russian)

Polchaninova N.Yu. (2020). Spiders (Aranei) of the 'Privolzhskaya Lesostep' Nature Reserve (Penza Area, Russia): the sector 'Kuncherovskaya Lesostep'. Arthropoda Selecta, 29(3), 371-386. https://doi.org/10.15298/arthsel.29.3.11

Polchaninova N.Yu., Prokopenko E.V. (2013). Catalogue of the spiders (Arachnida, Aranei) of Left-Bank Ukraine. Arthropoda Selecta, Supplement 2, 1-268.

Pyatin M.A. (1988). Spider species composition, numbers and habitat distribution in the Penza Area. The fauna and ecology of Arachnida. Perm: Perm University. P. 80-87. (in Russian)

Skorikov A.S. (1903). Report on the activity of the Volga Biological Station in 1902. Saratov. 62 p. (in Russian)

WSC. World Spider Catalog. (2020). Natural History Museum Bern. http://wsc.nmbe.ch, version 21.5.

\section{Нові відомості про фауну павуків (Araneae) Пензенської області (Росія)} Н.Ю. Полчанінова

Арахнологічні дослідження в Пензенській області проводилися лише у 1980-х та в середині 2000-х років. Спершу був опублікований список 112 видів та проаналізовано їхнє поширення в п'яти типах біотопів на території області (П'ятин, 1988). Пізніше павуки були досліджені на чотирьох ділянках природного заповідника «Приволзький 
лісостеп», розташованих у чотирьох адміністративних районах області, та складені видові списки для кожної ділянки (Полчанінова, 2008, 2015а, б, 2020). У цілому, в заповіднику знайдено 273 види павуків з 24 родин. Представлена стаття містить анотований список 71 виду павуків, уперше зібраних у Лунінському районі області. Матеріал збирався ґрунтовими пастками в 2004-2005 рр. у п'яти біотопах: луговий степ на чорноземному ґрунті на пологому схилі (32 види), степ на глинистому ґрунті на крутому схилі (33 види), степ на солонуватому ґрунті на пологому схилі (43 види), піщано-глиняний кар'єр (28 видів) та берег ставка (29 видів). Найчисленнішим виявилося угруповання павуків лучного степу (736 особин), де переважав Pardosa fulvipes (62 \% від загальної кількості павуків, зібраних у біотопі). Інші угруповання павуків були менш численними (мінімум 243 особини на березі ставка й максимум 324 особини в солонцевому степу), а їхня структура домінування була більш рівномірною. Домінантні комплекси складалися з Gnaphosa lugibris, Haplodrassus signifier і Xerolycosa miniata в глинистому степу (53\% павуків), X. miniata, $P$. fulvipes, $P$. palustris і $P$. agrestis у солонцевому степу $(60 \%)$, $X$. miniata і $P$. fulvipes у кар'єрі $(57 \%)$, та $P$. fulvipes, $P$. palustris і Diplostyla concolor на березі ставка $(63,5 \%)$. Таким чином, Pardosa fulvipes та Xerolycosa miniata були найчисленнішими видами на дослідженій території. Велика чисельність обох видів спостерігалася також на ділянці «Борок» природного заповідника «Приволзький лісостеп», що говорить про схожість екологічних умов у трав'янистих біотопах обох локалітетів. Один вид, Mastigusa arietina, є новим для Пензенської області. Разом із 40 видами, знайденими М. П'ятиним (1988), але відсутніми у наших пізніших зборах, фауна павуків Пензенської області нараховує 313 видів із 27 родин.

Ключові слова: аранеофауна, розповсюдження видів, степові біотопи, природоохоронні території, Приволзька височина.

\section{Про автора:}

Н.Ю. Полчанінова - Харківський національний університет імені В.Н. Каразіна, м. Свободи, 4, Харків, Україна, 61022, n.polchaninova@karazin.ua, http://orcid.org/0000-0003-4605-8788

\section{Новые сведения о фауне пауков (Araneae) Пензенской области (Россия) Н.Ю. Полчанинова}

Арахнологические исследования в Пензенской области проводились лишь в 1980-х и в середине 2000-х годов. Изначально был опубликован список 112 видов пауков и проанализировано их распространение в пяти типах биотопов на территории области (Пятин, 1988). Позже были составлены аннотированные списки пауков четырех участков природного заповедника «Приволжская лесостепь», расположенных в четырех административных районах области (Полчанинова, 2008, 2015а, б, 2020). В целом в заповеднике было найдено 273 вида пауков из 24 семейств. В данной статье представлен аннотированный список 71 вида пауков, впервые собранных в Лунинском районе области. Материал собирался почвенными ловушками в 2004-2005 гг. в пяти биотопах: луговая степь на черноземных почвах на пологом склоне (32 вида), степь на глинистой почве на крутом склоне (33 вида), степь на солонцовой почве на пологом склоне (43 виды), песчано-глиняный карьер (28 видов) и берег пруда (29 видов). Самым многочисленным оказалось сообщество пауков луговой степи (736 особей), где преобладал Pardosa fulvipes (62 \% от общего количества пауков, собранных в биотопе). Другие сообщества пауков были беднее (минимум 243 особи на берегу пруда и максимум 324 особи в солонцовой степи). Их структура доминирования была более равномерной. Доминантные комплексы состояли из Gnaphosa lugibris, Haplodrassus signifier и Xerolycosa miniata в глинистой степи (53\% пауков), X. miniata, P. fulvipes, P. palustris и P. agrestis в солонцовой степи $(60 \%)$, X. miniata и $P$. fulvipes в карьере $(57 \%)$ и $P$. fulvipes, $P$. palustris и Diplostyla concolor на берегу пруда (63,5\%). Таким образом, Pardosa fulvipes и Xerolycosa miniata были самыми многочисленными видами на обследованной территории. Высокая численность обоих видов зафиксирована также на участке «Борок» природного заповедника «Приволжская лесостепь», что говорит о сходстве экологических условий в травянистых биотопах обоих локалитетов. Один вид, Mastigusa arietina, является новым для Пензенской области. Вместе с 40 видами, найденными М. Пятиным (1988), но отсутствующими в наших более поздних сборах, фауна пауков Пензенской области насчитывает 313 видов из 27 семейств.

Ключевые слова: аранеофауна, распространение видов, степные биотопы, природоохранные территории, Приволжская возвышенность.

\section{Oб авторе:}

Н.Ю. Полчанинова - Харьковский национальный университет имени В.Н. Каразина, пл. Свободы, 4, Харьков, Украина, 61022, n.polchaninova@karazin.ua, http://orcid.org/0000-0003-4605-8788

Подано до редакції / Received: 30.08.2020 